Fitria Novita Sarie, S.Pd, M.Pd : Optimalisasi Pembelajaran Daring Masa Pandemi Covid-19 Melalui Apliasi Edmodo Bagi Peserta Didik Sekolah Dasar

\title{
OPTIMALISASI PEMBELAJARAN DARING MASA PANDEMI COVID-19 MELALUI APLIKASI EDMODO BAGI PESERTA DIDIK SEKOLAH DASAR
}

\author{
Fitria Novita Sarie, S.Pd., M.Pd. \\ SD 1 Tanjungkarang Jati Kudus \\ sariefitria44@gmail.com
}

\begin{abstract}
ABSTRAK
Mewabahnya Corona Virus Disease atau lebih dikenal dengan COVID-19 membuat pengalaman baru dalam dunia pendidikan. Pemerintah mengeluarkan kebijakan untuk meliburkan peserta didik dan menggantinya dengan Belajar Dari Rumah (BDR). Sistem pembelajaran dalam jaringan (daring) atau online menjadi satu-satunya pilihan yang harus dijalankan oleh guru agar peserta didik tetap memperoleh pembelajaran meskipun berada dirumah. Peserta didik usia Sekolah Dasar belum sepenuhnya menguasai media internet, oleh karena itu guru dituntut untuk mendesain pembelajaran daring yang ringan dan efektif agar seluruh peserta didik dapat mengaksesnya dengan mudah. Pembelajaran daring melalui WA dianggap menjenuhkan oleh sebagian besar peserta didik. Penelitian ini menjadi solusi untuk mengatasi permasalahan tersebut. Metode Penelitian ini merupakan penelitian quasi eksperimen, dengan desain pre-test and post-test group design. Teknik pegumpulan data menggunakan tes dan nontes. Hasil penelitian menunjukkan bahwa Edmodo efektif digunakan dalam pembelajaran daring. Hal ini dibuktikan dengan meningkatnya antusiasme peserta didik saat pembelajaran daring berlangsung yaitu sebesar $80 \%$. Hasil belajar peserta didik juga mencapai kategori sangat baik yaitu sebanyak $80 \%$ siswa tuntas Kriteria Ketuntasan Minimal (KKM).
\end{abstract}

Kata Kunci: Edmodo, Pembelajaran Daring, Sekolah Dasar

\section{ABSTRACT}

The outbreak of Corona Virus Disease or better known as COVID-19 creates a new experience in the world of education. The government issued a policy to exclude students and replace them with Learning From Home (BDR). An online learning system is the only option that must be run by the teacher so that students can still get learning even at home. Elementary school-age learners are not yet fully mastering internet media, therefore teachers are required to design lightweight and effective online learning so that all students can access it easily. Online learning through WA is considered saturating by most learners. This research becomes a solution to overcome the problem. This research method is an experimental quasi research, with pre-test and post-test group design. Data collection techniques using tests and nontest. The results showed that Edmodo is effectively used in online learning. This is evidenced by the increasing enthusiasm of learners during online learning by $80 \%$. The learning outcomes of the students also reached a very good category, namely as many as $80 \%$ of students completed the Minimum Completion Criteria (KKM).

Keywords: Edmodo, Online Learning, Elementary School 
Fitria Novita Sarie, S.Pd, M.Pd : Optimalisasi Pembelajaran Daring Masa Pandemi Covid-19 Melalui Apliasi Edmodo Bagi Peserta Didik Sekolah Dasar

\section{PENDAHULUAN}

Menjamurnya Corona Virus Disease atau lebih dikenal dengan COVID-19 membuat pengalaman baru dalam dunia pendidikan. Virus corona adalah jenis baru dari virus yang menyebabkan penyakit menular ke manusia. Virus corona berasal dari kota Wuhan, China yang mewabah pada Desember 2019. Hampir semua negara terpapar virus ini , termasuk Indonesia. Seluruh kegiatan belajar mengajar di sekolah dihentikan dan diganti Belajar dari Rumah. Surat Edaran Menteri Pendidikan(2020) menyebutkan bahwa sekolah dilarang memasukkan peserta didik dan seluruh pembelajaran diganti dengan sistem daring (dalam jaringan). Hal ini menuntut kreativitas dan inovasi guru dalam mengelola pembelajaran secara daring melalui internet. Sistem pembelajaran daring yang umum dilaksanakan yaitu guru yaitu menggunakan aplikasi Whats App (WA) karena dianggap mudah dan biasa dipakai oleh peserta didik. Guru membuat grup kelas kemudian mengirim materi dan tugas melalui group tersebut.

Hasil evaluasi pembelajaran melalui WA selama setengah semester, pembelajaran daring melalui WA dianggap menjenuhkan oleh peserta didik karena tidak di dukung oleh fitur-fitur yang lengkap. Peserta didik kurang bersemangat karena mereka hanya sebatas dapat membaca pesan dan menggunakan voice note, diskusi antar teman juga terasa kurang optimal akibatnya hanya beberapa peserta didik saja yang aktif saat pembelajaran daring berlangsung. Penelitian Dewi (2020) menunjukkan bahwa adanya pendemi covid-19 sangat berdampak pada implementasi pembelajaran daring di sekolah. Kurangnya fasilitas handphone dan kuota internet menjadi salah satu penyebab terhambatnya pembelajaran secara online. Hasil penelitian Sari (2019) menjelaskan bahwa Penggunaan E-Learning Berbasis Edmodo terbukti efektif dalam meningkatkan Kemampuan Komunikasi Matematika. Kedua penelitian tersebut yang mendasari peneliti untuk memilih Edmodo dalam pembelajaran daring di Sekolah Dasar.

Edmodo diciptakan oleh sebuah perusahaan ilmu pengetahuan dan teknologi bagi para penggiat pendidikan yang dapat dijadikan tempat untuk belajar bagi guru, peserta didik, dan orangtua. Edmodo berbentuk seperti social media sehingga sangat menarik untuk digunakan. Di dalam platform Edmodo ini baik pengajar maupun peserta didiknya 
Fitria Novita Sarie, S.Pd, M.Pd : Optimalisasi Pembelajaran Daring Masa Pandemi Covid-19 Melalui Apliasi Edmodo Bagi Peserta Didik Sekolah Dasar

dapat saling berinteraksi dengan mudah. Peserta didik, guru, dan orangtua dapat mengakses aplikasi ini dengan mudah yaitu dengan mendownload di playstore kemudian mendaftar.

Bagi guru, aplikasi ini sangat mendukung proses pembelajaran secara daring karena terdapat menu-menu yang lengkap, mulai dari share materi dari berbagai sumber, pembagian tugas dan kuis yang dapat di akses secara online. Guru juga dapat langsung melakukan penilaian dengan cara memantau siswa yang sudah maupun belum menyelesaikan tugasnya. Manfaat bagi peserta didik, melalui Edmodo ini peserta didik dapat menyimak materi yang disampaikan oleh guru, kemudian mengecek tagihan-tagihan tugas dan kuis yang harus diselesaikan. Menggunakan aplikasi Edmodo sama halnya dengan menggunakan facebook. Layaknya sosial media bagi para pegiat pendidikan, Edmodo membantu peserta didik untuk berkomunikasi dengan peserta didik lainnya meskipun berbeda daerah bahkan negara. Selain guru dan peserta didik, orangtua peserta didik juga dapat menggunakan aplikasi Edmodo ini untuk meninjau perkembangan belajar peserta didik.

Hasil dari analisis tersebut, maka penelitian ini bertujuan untuk mengoptimalkan pembelajaran daring yang mudah dan menyenangkan bagi peserta didik Sekolah Dasar yaitu dengan aplikasi Edmodo.

\section{METODE PENELITIAN}

Penelitian ini merupakan penelitian quasi eksperimen, dengan desain pre-test and post-test group design. Teknik pegumpulan data menggunakan tes dan nontes. Tes dalam penelitian ini digunakan untuk mengukur hasil belajar kognitif peserta didik. Teknik non tes dilakukan dengan teknik observasi. Observasi digunakan untuk mengamati aktivitas peserta didik menggunakan instrumen berupa check list. Analisis data menggunakan analisis deskriptif kuantitatif dan analisis deskriptif kualitatif. 
Fitria Novita Sarie, S.Pd, M.Pd : Optimalisasi Pembelajaran Daring Masa Pandemi Covid-19 Melalui Apliasi Edmodo Bagi Peserta Didik Sekolah Dasar

\section{HASIL DAN PEMBAHASAN}

Hasil penelitian menunjukkan bahwa pembelajaran daring menggunakan aplikasi Edmodo menunjukkan peningkatan aktivitas belajar peserta didik dari sebelumnya. Sebelum penelitian, persentase aktivitas belajar daring peserta didik hanya sebesar $45 \%$. Sebagian besar peserta didik tidak aktif atau enggan mengikuti pembelajaran daring karena dirasa membosankan. Setelah menggunakan aplikasi Edmodo, aktivitas belajar peserta didik meningkat $35 \%$ menjadi $80 \%$. Peserta didik sangat antusias mengikuti pembelajaran karena mereka senang dengan fitur-fitur yang ada di Edmodo. Peningkatan aktivitas peserta didik dalam pembelajaran, dinyatakan dengan persentase dalam diagram 1.

Diagram 1. Peningkatan Aktivitas Belajar Peserta didik Sebelum dan Sesudah Penelitian

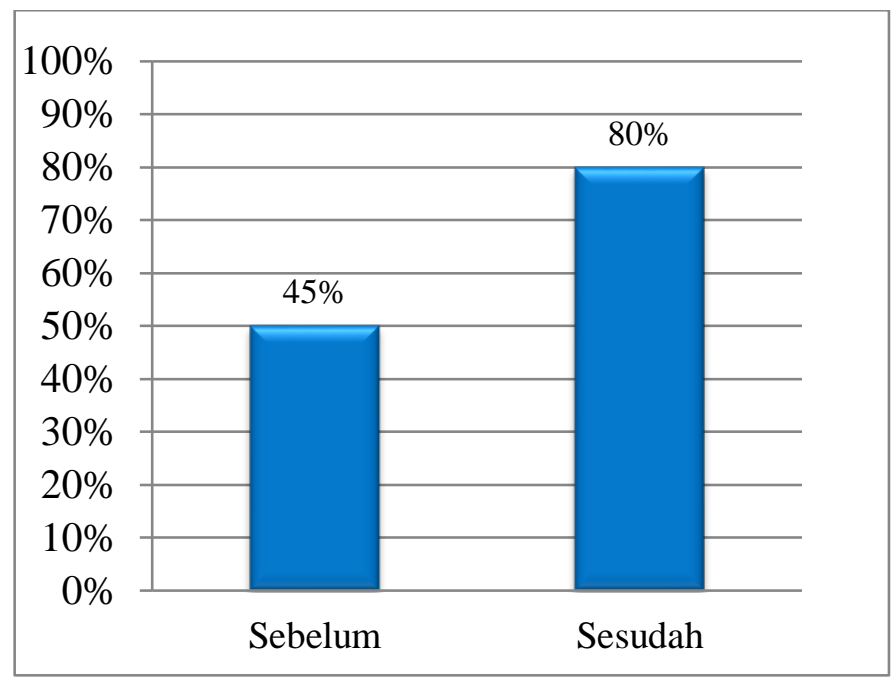

Selain aktivitas belajar peserta didik, hasil belajar kognitif peserta didik sebelum dan sesudah penelitian juga meningkat. Terjadi peningkatan Ketuntasan Klasikal Hasil Belajar Peserta didik sebesar 30\% sebelum dan sesudah penelitian. Sebelum penelitian dilakukan, peserta didik yang tuntas KKM hanya 50\%. Setelah dilakukan penelitian meningkat sebesar $30 \%$ yaitu mencapai $80 \%$. Adapun grafik peningkatan Ketuntasan Klasikal Hasil Belajar Peserta didik sebelum dan sesudah penelitian dapat dilihat pada diagram 2. 
Diagram 2. Peningkatan Ketuntasan Klasikal Hasil Belajar Peserta didik Sebelum dan Sesudah Penelitian

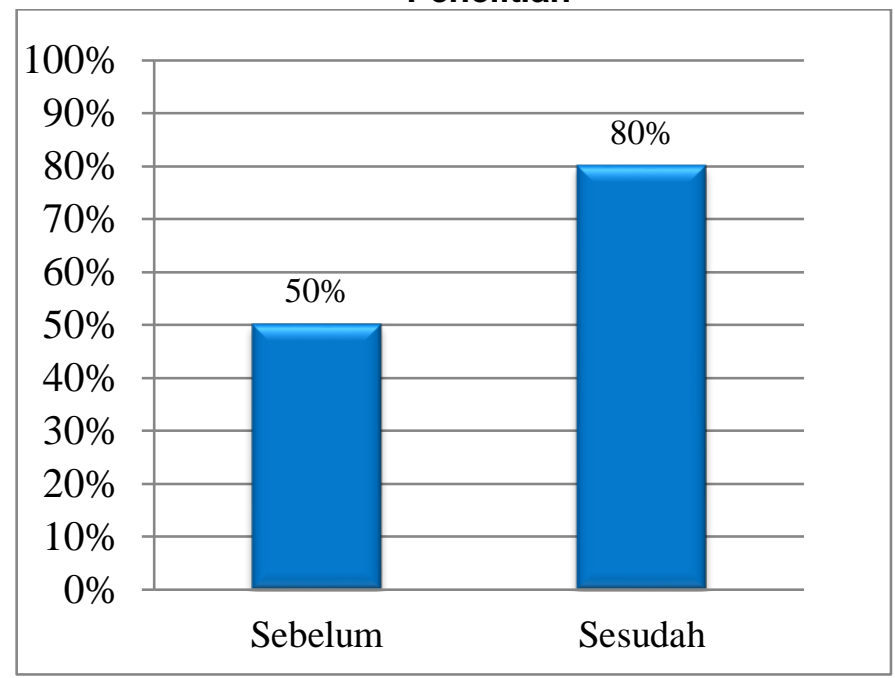

Diagram diatas menunjukkan bahwa aplikasi Edmodo mampu mengoptimalkan pembelajaran daring, hal ini terbukti dari meningkatknya aktivitas peserta didik dalam pembelajaran secara jarak jauh. Peserta didik antusias dan tepat waktu dalam memulai pembelajaran dari rumah. Pertama-tama mereka menuliskan kabar kemudian menyimak materi yang diberikan oleh guru. Setelah memahami materi kemudian peserta didik mengecek tagihan tugas untuk dikerjakan. Ada batas waktu yang diberikan guru untuk mengerjakan tugas. Setelah tugas terpenuhi kemudian peserta didik dapat berdiskusi dengan guru maupun teman-temannya tentang kesulitan yang diahadapi. Sebanyak $80 \%$ peserta didik merasa senang dengan aplikasi Edmodo ini, mereka seperti belajar sambil bermain sosial media. Pada akhir pertemuan peserta didik mengerjakan kuis untuk mengetahui pemahaman hasil belajar mereka. Sebanyak $80 \%$ siswa mendapat nilai sangat baik, maka disimpulkan bahwa aplikasi Edmodo mampu mengoptimalkan pembelajaran daring bagi peserta didik sekolah dasar. Penyataan ini didukung penelitian oleh Al-Anshori (2019) yang menyatakan bahwa terdapat pengaruh penggunakan aplikasi Edmodo terhadap efektifitas pembelajaran, hasil tes menunjukkan ketuntasan klasikal sebesar $80 \%$ pada kelompok yang 
Fitria Novita Sarie, S.Pd, M.Pd : Optimalisasi Pembelajaran Daring Masa Pandemi Covid-19 Melalui Apliasi Edmodo Bagi Peserta Didik Sekolah Dasar

menggunakan aplikasi Edmodo, sehingga dapat disimpulkan pembelajaran menggunakan aplikasi edmodo efektif dalam melakukan evaluasi dan pemberian tugas kepada mahasiswa.

\section{SIMPULAN}

Aplikasi Edmodo menjadi sarana yang efektif dalam mengoptimalkan pembelajaran daring bagi peserta didik Sekolah Dasar. Hal ini dibuktikan dengan antusiasme peserta didik yang sangat baik pada saat pembelajaran berlangsung yaitu sebesar $80 \%$. Hasil belajar peserta didik sebanyak $80 \%$ peserta didik memperoleh nilai sangat baik.

\section{DAFTAR PUSTAKA}

Abidin, Z., Rumansyah, Arizona, K. (2020). Pembelajaran online berbasis proyek salah satu solusi kegiatan belajar mengajar di tengah pandemi covid-19. Jurnal Ilmiah Profesi Pendidikan, 5(1), 2620-8326

Adit, A. (2020). 12 Aplikasi Pembelajaran Daring Kerjasama Kemendikbud, Gratis!. https://edukasi.kompas.com/read/2020/03/22/123204571/12-aplikasipembelajaran-daring- (Online) Tersedia : kerjasama-kemendikbudgratis?page=all

Al-Anshori, Fitrah. Pengaruh Penggunaan Aplikasi Edmodo Terhadap Efektivitas Pembelajaran Mahasiswa Pendidikan Biologi. Jurnal Biogenerasi. 4 (2): 8-17

Dewi, Wahyu Aji Fatma. (2020) Dampak Covid-19 terhadap Implementasi Pembelajaran Daring di Sekolah Dasar Edukatif Jurnal IImu Pendidikan. 2 (1)

Menteri Pendidikan. (2020). Surat Edaran Nomor 3 Tahun 2020 Tentang Pelaksanaan Pendidikan dalam Masa Darurat CoronaVirus (COVID-19)

Sari, Nilam, dkk. 2019. Efektivitas Penggunaan E-Learning Berbasis Edmodo Terhadap Kemampuan Komunikasi Matematika. Jurnal Curere. 3 (2). 